\title{
Miranda
}

Revue pluridisciplinaire du monde anglophone /

Multidisciplinary peer-reviewed journal on the English-

speaking world

13 | 2016

Thomas Spence and his Legacy: Bicentennial

Perspectives

\section{AS - Poetic Justice, Endings and Epilogues in Sense and Sensibility}

Armelle Parey

\section{OpenEdition}

\section{Journals}

Electronic version

URL: http://journals.openedition.org/miranda/9384

DOI: $10.4000 /$ miranda.9384

ISSN: 2108-6559

\section{Publisher}

Université Toulouse - Jean Jaurès

Electronic reference

Armelle Parey, "AS - Poetic Justice, Endings and Epilogues in Sense and Sensibility", Miranda [Online],

13 | 2016, Online since 23 November 2016, connection on 16 February 2021. URL: http:// journals.openedition.org/miranda/9384 ; DOI: https://doi.org/10.4000/miranda.9384

This text was automatically generated on 16 February 2021

\section{(c) (i) (9)}

Miranda is licensed under a Creative Commons Attribution-NonCommercial-NoDerivatives 4.0 International License. 


\title{
AS - Poetic Justice, Endings and Epilogues in Sense and Sensibility
}

\author{
Armelle Parey
}

\section{Introduction}

1 The notion of poetic justice was propounded by Thomas Rymer in The Tragedies of the Last Age Consider'd (1678) where he suggested characters should be rewarded according to their virtues : "something must stick by observing that constant order, that harmony and beauty of Providence, that necessary relation and chain, whereby the causes and the effects, the vertues and rewards, the vices and their punishments are proportion'd and link'd together" (75). Dictionaries of literary terms explain that poetic justice ensures the prevalence of morality - retributed by material rewards - and they clearly establish that the ending is the privileged locus for the distribution of just deserts : in M. H. Abrams' words, poetic justice is "the distribution, at the end of a literary work, of earthly rewards and punishments in proportion to the virtue or vice of the various characters" (230, italics mine)," and for Chris Baldick, "the morally reassuring allocation of happy and unhappy fates to the virtuous and the vicious characters respectively, usually at the end of a narrative or dramatic work"(197, italics mine).

Even though poetic justice originally applies to drama and tragedy, the concept permeates the English novel and finds its expression in death or marriage at the end. ${ }^{1}$ In David Lodge's words, "the marriage knot is the primary symbol of happiness, of the optimistic idea that the nice and the good are one and shall inherit the earth.[...] we enjoy the reassurance that stories provide, the reassurance that there is a meaningful order in reality" (149). As pointed out by Lodge, the retribution of worthy characters, ensured by poetic justice, is something the contemporary reader tends to aspire to but in the 18th century, it was a necessary component of the didactic novel the aim of which was indeed to edify readers and warn them against evil behaviour, which implied a moral ending with necessarily appropriate rewards as in Samuel Richardson's Pamela and Fanny Burney's Evelina. 
3 Jane Austen's Sense and Sensibility (1811), unlike her following novels, bears some of the characteristics of a didactic novel and was first received as such (see Butler 182). Austen duly rewards her heroines with a marriage but the question arises as to whether these marriages are a sign of poetic justice whose existence is not a given in Sense and Sensibility. Indeed, while Lloyd Brown notes "Austen's characteristic disregard for the niceties of poetic justice" (1585) which he attributes to the writer's commitment to realism (in a context of formulaic novels) ${ }^{2}$, Aurélie Tremblet asserts that poetic justice prevails at the end of Austen's Sense and Sensibility as heroines and heroes see their virtues and their efforts rewarded (52-53). These contrasting views point to an ambiguity inherent in the text which will be explored in the course of this paper. One may wonder what happens to this ambiguity regarding poetic justice when such the novel is adapted to the screen - as it was by Ang Lee in 1995 in a Columbia pictures production with famous actors and actresses on a high budget - considering adaptations often lose in subtlety and prefer to promote a marked happy ending (Hudelet 77). ${ }^{3}$

4 This paper thus proposes to re-examine the presence - ambiguous or not - of poetic justice in the endings of the novel and of its film adaptation as an indication of the critical commentary each work offers on society. I shall first focus on the question of the attribution or not of material rewards to the characters before questioning what has become one of the hallmarks of poetic justice : the romantic resolution. Ang Lee's adaptation will be examined along with Austen's novel but my third part will be entirely devoted to the film as the popularity of Austen's novels today is due, at least partly, to the happy ending that film adaptations display. Indeed, according to Kathryn Sutherland, "[c]urrent adaptations are part of the rebranding of Jane Austen as the godmother of $21^{\text {st }}$-century romance" $(219-20)$.

\section{Of material rewards}

5 "[T]his dark and disenchanted novel" (Johnson 49) begins with a sense of injustice : firstly, for no fault of theirs, the heroines of Sense and Sensibility are deprived of inheritance and, secondly, they are "degraded to the condition of visitors" (6) in what used to be their home until they are made to feel they had better leave by Fanny's avarice and unfriendliness (6). In other words, the heroines are enmeshed in an economic system - male primogeniture - that does not consider them but they are also up against individuals that may use this system and benefit from it : Elinor, Marianne, Margaret, and their mother are at the mercy of the whim of the "old gentleman" who changes the beneficiary of his estate and, consequently places them in the hands of John and Fanny Dashwood. Introduced at the end of the first chapter, that is, when everything has been settled for them, the three girls have no say in their fate.

6 The principle of poetic justice demands that, by the end of the novel, the wrongs unduly done to the innocent Dashwood women be redressed and they regain their status. Contemporary "disinheritance novels," Olivia Murphy tells us, usually displayed a final change of heart which reinstated the heroine/hero in his/her own rights but this is out of the question in Sense and Sensibility: "Austen forecloses on any such gratuitously happy ending by killing off the unnamed 'old Gentleman,' the proprietor of Norland, in her first chapter" (81). Indeed, in accordance with the dark tone of the incipit, Elinor and Marianne do not exactly regain their wealth and status at the end of 
the novel, and their rewards (i.e. marriage and economic security) may be considered incomplete. Moreover, the ending of the novel leaves them established and settled but their new situation is not necessarily equal or related to their virtues. In terms of wealth, they obtain satisfaction as they gain the competence they each wanted (see Copeland 129). Yet, on the whole, as Claudia Johnson notes, positive heroes are not rich at the end of Sense and Sensibility, and wealth is eventually left to "moral nullities" (69). ${ }^{4}$ Indeed, Robert Ferrars and John Dashwood - neither of whom appearing as a deserving character - both enjoy a fortune that is theirs thanks to somebody else's decision and remain impervious to the unfairness of the situation: Robert Ferrars's (wilful or not) unawareness of the injustice done to his brother recalls John Dashwood's attitude towards his sisters at the beginning. ${ }^{5}$ Thus, to a certain extent, injustice and selfishness frame the novel.

Unfairness could indeed be said to be the prevailing theme of the last chapter which, functioning as epilogue, lists the fortunes of the main characters. In this closing section, the narrator dwells on the injustice surrounding Miss Dashwood while Lucy becomes a favourite in the Ferrars family: "Elinor, though superior to her in fortune and birth, was spoken of as an intruder" (287). Inequity is also highlighted when it comes to Edward who pays for his integrity - shown in his keeping his word to Lucy with the loss of his inheritance (whereas his brother Robert actually commits what is seen as a misalliance without losing anything).

Elinor certainly gets her heart's desire in the shape of Edward, but it is significantly not due to her merits only. Indeed, while poetic justice implies that characters are rewarded for their virtues, Elinor can marry Edward only because Lucy has released him of his promise to her. In Claudia Johnson's words, "Austen makes the happy outcome of the novel as a whole contingent upon Lucy Steele's hardhearted but redemptive "second attachment" for Robert Ferrars" (69). Elinor's happiness thus depends on Lucy's relentless fortune-hunting and not only on her own qualities, which means that virtue - as in moral excellence - is not rewarded in the society the Dashwood sisters live in.

9 Not only are probity and worthiness not rewarded but the "villains" are not punished. To use and adapt Rymer's words, the vices and their punishments are not proportioned and linked together. They may enjoy very limited domestic bliss indeed ${ }^{6}$ but what matters to them is economic success and a high social rank and they enjoy both. The narrator spends many paragraphs describing how Lucy Steele and Robert Ferrars recover Mrs Ferrars's favours. Yet, irony deflates their position as overall winners so that the reader is left in doubt of the immorality of their success :

The whole of Lucy's behaviour in the affair, and the prosperity which crowned it, therefore, may be held forth as a most encouraging instance of what an earnest, an unceasing attention to self-interest [...] will do in securing every advantage of fortune, with no other sacrifice than that of time and conscience (286).

The pace, rhythm and theme of this sentence that offers to draw a lesson from the success of Lucy's strategy all combine to make it sound like the moral of the story and a mockery of didactic novels. The end-focus principle however makes the emphasis of the sentence fall on the meiosis, on the clause that ironically reminds the reader of the actual cost of Lucy's success.

11 Willoughby apparently gets his just deserts insofar as he is now wealthy but does not experience marital harmony and regrets Marianne. The regret and its inherent misery 
are insisted on by Ang Lee in the final shots where a lonely Willoughby is seen observing Marianne's wedding from a distance whereas Austen's ironic tone puts forwards the long list of material consolations : "in his breed of horses and dogs, and in sporting of every kind, he found no inconsiderable degree of domestic felicity" (289). The end focus again lays the emphasis on a figure of speech, a litotes, which ironically states Willoughby's unhappiness is in fact minor. There is indeed no doubt in Austen's novel as to who is deserving or not but the author deliberately refrains from applying poetic justice.

12 Just as in Northanger Abbey, where she attracts the reader's attention to the closure of the novel : "my readers [...] will see in the tell-tale compression of the pages before them, that we are all hastening together to perfect felicity" (203), Austen ostentatiously declines to display poetic justice at the end of Sense and Sensibility as suggested by the recurrence of its keywords "reward" (287) in relation to Colonel Brandon, and "punishment" (288), twice, in relation to Willoughby. The words are indeed ironically misapplied as, in the first instance, the stress is laid not on the retribution of Brandon's undeniable merits but on the merchandising of Marianne whom the other characters have decided is to be the colonel's reward: "They each felt his sorrows, and their own obligations, and Marianne, by general consent, was to be the reward of all" (287). In the second instance, the meaning and weight of the word "punishment" is deflated, firstly, by the fact that it is linked to Willoughby's reinstatement as heir to Allenham which brings him more riches ${ }^{7}$ and, secondly, by the long list that follows of what the young man did NOT renounce after losing Marianne.

But that he was forever inconsolable, that he fled from society, or contracted an habitual gloom of temper, or died of a broken heart, must not be depended on-for he did neither" (288-289).

13 There is no poetic justice in Sense and Sensibility because, as we have seen with the material and society success of the "villains", its fictional world is not ruled by morality. Elinor and Marianne do not compromise their moral principles and live in harmony but they are clearly signalled as exceptions in a world that does not really value them insofar as it belongs to the John Dashwoods, the Mrs Ferrars and the Lady Middletons. While Pride and Prejudice ends on the marriage and understanding of two different sets embodied by Elizabeth Bennet and Darcy, Sense and Sensibility offers no such positive alliance. There is no final reconciliation with John and Fanny Dashwood nor with the Ferrars. The Dashwood sisters, with their new husbands, constitute a world apart, embodied in the distance at which they live from the others and shown by Ang Lee with shots of a simple country wedding, away from fashionable London. Moreover, the very last paragraph, while celebrating Marianne and Elinor's good fortune in living harmoniously and close to each other, nevertheless at the same time alludes to possible conflicting situations, setting off the sisters' concord as rare :

and among the merits and the happiness of Elinor and Marianne, let it not be ranked as the least considerable, that though sisters, and living almost within sight of each other, they could live without disagreement, or producing coolness between their husbands (289).

14 In Sense and Sensibility, through the use of irony which establishes a discrepancy between what is said and what is meant, a very moral point is made that laments the absence of morality in a society that does not properly reward its virtuous characters but celebrates unscrupulous ones like Lucy and Robert Ferrars. In other words, this 
absence of poetic justice is an indictment of a society that lacks morality and allows the villains to enjoy undeserved wealth and respectability.

\section{Romantic resolutions?}

15 Happy marriages are a regular retribution in comedy and romance, the genres with which Austen's novels tend to be commonly, if not always accurately, associated. For Vivien Jones,

Her realism is tempered by romance: an essentially conservative form. Happilyever-after endings, which conveniently combine material comfort with emotional satisfaction, are her heroines' reward for their moral integrity and for refusing to marry merely for mercenary convenience. (285)

Vivien Jones neglects here to mention the self-conscious, dismissive or elliptical presentation of the romantic resolutions Austen displays in her novels, such as, for instance, the extreme brevity of the love declaration that is significantly reported in indirect style in Northanger Abbey: "She was assured of his affection; and that heart was in turn solicited" (198) or, the reticence in Pride and Prejudice which merely states with irony "he expressed himself on the occasion as sensibly and as warmly as a man violently in love can be supposed to do" (375) while Sense and Sensibility declines to give the particulars of both engagements - about Edward Ferrars, the narrator says : "in what manner he expressed himself, and how he was received, need not be particularly told" (274).

Sense and Sensibility does end on the double wedding of the sisters but the novel displays features that downplay the happy ending. Firstly, few marriages are presented as happy ones in the course of the novel. In Brownstein's words, "Its portraits of the marriages already made are clear signs of the novel's darkness" (46) : when meeting the Middletons and the Palmers, Elinor has occasion to muse on "the strange unsuitableness which often existed between husband and wife" (89). When introducing the Middletons, the parataxis - the juxtaposition of clauses without connectors mirrors the fact that the characters live side by side but have nothing in common : "Sir John was a sportsman, Lady Middleton a mother. He hunted and shot, she humoured her children; and these were their only resources" (25). The Palmers are another mismatched couple and, in the film, the physical contrast between the two actors embodying them - small plump Imelda Staunton and tall lean Hugh Laurie - offers a comic visual representation of their ill-assortedness.

Secondly, critics and readers have regularly expressed their dissatisfaction with the concluding unions offered. Rachel Brownstein, for instance, declares that "Sense and Sensibility comes to a thoroughly unromantic resolution, coupling Marianne with the colonel in the flannel waistcoat, and Elinor [...] with the familiar, hapless Edward." (48). ${ }^{8}$ In the latter's case, the narrator seems to adopt Marianne's viewpoint and deny the strength of their feelings when asserting "they were neither of them quite enough in love to think that three hundred and fifty pounds a-year would supply them with the comforts of life" (280). In fact, rather than belittling Edward and Elinor's feelings for each other, the sentence mocks the excesses displayed in sentimental novels. The text is more ambiguous still regarding Marianne, with assertions accompanied by amendments. Indeed, when Marianne marries, she is not in love : "with no sentiment superior to strong esteem and lively friendship" (288) but this is shortly corrected by 
"Marianne could never love by halves ; and her whole heart became, in time, as much devoted to her husband, as it had once been to Willoughby" (288). The emphasis is laid on new beginnings for her in "she found herself at nineteen, submitting to new attachments, entering on new duties, places in a new home, a wife, the mistress of a family, and the patroness of a village" (288). Yet, it seems to be downplayed by the passive value of "she found herself" and "placed" that suggest that all this is happening to her without her initiative, that these new elements do not answer her own particular wishes. Marianne marries a man "who still sought the constitutional safeguard of a flannel waistcoat !" (288) which Brownstein reads as a sign of Marianne's mismatch (see quote above). The mention of the colonel's flannel waistcoat again in the last chapter can however be seen as humorous as suggested by the exclamation mark. Moreover, it was originally an indication of the heroine's simplistic views and shortcuts: "But he talked of flannel waistcoats,' said Marianne; 'and with me a flannel waistcoat is invariably connected with aches, cramps, rheumatisms, and every species of ailment that can affect the old and the feeble." (30). The final allusion is therefore not necessarily negative but may be read as proof that Marianne has grown out of some of her prejudices. Finally, the text also lets us know that, fed by Marianne's "regard," Colonel Brandon previously repeatedly described as "grave" gains in "animation" and "cheerfulness" (288). The couple reaches the middle ground advocated by Austen : a balanced blend of sense AND sensibility. The final unions are thus part of Austen's scheme of reward but the latter may seem quite limited.

The reader and viewer's appreciation of poetic justice depends on what the text and the film have said before. The "unromantic" dimension of the ending pointed by Brownstein, the doubt about the reality of the pallid-seeming love resolution is also partly due to the fact that contrary to Darcy in Pride and Prejudice and to Mr Knightley in Emma, the male heroes of Austen's Sense and Sensibility are quite deficient. "(A) gentlemanlike and pleasing young man" (12), Edward is nevertheless portrayed through a series of negatives that make out a bland character : "Edward Ferrars was not recommended to their good opinion by any particular graces of person or address. He was not handsome, and his manners required intimacy to make them pleasing." (12); Mrs Dashwood appreciates the fact that he is "quiet and unobtrusive" (13). In fact, he is absent for the best part of the novel and when present, he is not very forthcoming (as he is hiding his engagement with Lucy) or is markedly helped by Elinor as in volume II, chapter 13 when he visits Elinor and unexpectedly finds Lucy with her. The narrator mocks his embarrassment: "They all looked exceedingly foolish; and Edward seemed to have as great an inclination to walk out of the room again, as to advance farther into it" (180) followed by "[Elinor's] manners gave some re-assurance to Edward, and he had courage enough to sit down" (181). As for Colonel Brandon, he is first introduced as "silent and grave" (27) - the second attribute being applied to him throughout the novel- and "not handsome" (27), in marked contrast to Willoughby, his "uncommonly handsome" rival (33). For Kristin Flieger Samuelian, this blandness in the male heroes points to Elinor and Marianne's limited options: "no single one of the novel's male characters has the substance to adequately partner either of its heroines, and [...] both end up marrying men whose combined integrity and passionlessness demonstrate the limited choices available to middle-class women"(155). Edward Ferrars and Colonel Brandon's limits as heroes can however also be read as Austen's voluntary departure from sentimental novels and their excesses embodied in the character of Willoughby. Alternatively, this unromantic dimension of the heroes and the two weddings in the 
novel can be explained by the link between the two sisters being the most important one, as suggested by the very last paragraph that is devoted first and foremost to their relationship, which has sometimes been read as superior to the marital link. In Rachel Brownstein's words, "the concluding paragraph brilliantly undoes the requisite romantic conclusion, by startlingly giving Elinor's and Marianne's attachment to one another pride of place, so as to make their second attachments, their husbands, seem merely secondary" $(48)^{9}$. It is true that narrator significantly returns to the bond between the sisters at the end of a general overview of all the characters and incorporates their new married state into the bond: "they could live without disagreement between themselves, or producing coolness between their husbands" (289). The sisters' harmonious relationship is given weight by its thematic position in the final paragraph and this bond is shown to continue to exist in the married state.

What can be safely concluded here is that the romantic resolution in Sense and Sensibility is nuanced and measured, notably because of the passionless or un-romantic nature of the heroes, and does not supersede the bond between the sisters. No such conclusions are to be derived from Ang Lee and Emma Thompson's film in which the heroes have been improved via the choice of handsome actors and/or the transfer of some qualities. Colonel Brandon has indeed come to share some of the positive qualities of Austen's Willoughby as appears, for instance, in his reading poetry to Marianne. In the film, there is thus no suggestion that either Elinor or Marianne is losing out. ${ }^{10}$ Moreover, as noted by Penny Gay and by James Thompson, the film lays the emphasis on sisterhood to the extent that, according to Gay who echoes Brownstein's remarks above about the text, it overshadows the conjugal relationship: "Patriarchally sanctioned heterosexual marriage - in which as Austen and the filmmakers made clear, money and property have their incontrovertible place - is emotionally shallow compared with the bond of sisters who have (potentially) nothing but one another" (Gay 105). The film certainly shows the sisters' intimacy and trust recovered with their walk by the seaside discussing Willoughby, yet it does not end on a two-shot of Elinor and Marianne but on a romantic country wedding.

\section{Visual representation}

21 Ang Lee's Sense and Sensibility displays the same two final phases pointed out by David Bordwell in classical Hollywood movies : the resolution ("the untying") is followed by the epilogue which - as in a novel - "functions to represent the final stability achieved by the narrative : the characters' futures are settled" ("Happily" 4). The epilogue is the privileged place for poetic justice : "an extrinsic norm, the need to resolve the plot in a way that yields 'poetic justice,' provides a structural constant, inserted with more or less motivation into its proper slot, the epilogue" (Bordwell Narration 159). Indeed, while, as shown above, Austen deliberately resisted poetic justice in the epilogue to her novel, Ang Lee's conveys a different atmosphere in his adaptation.

The last four minutes of the film - a separate unit on the DVD tellingly entitled "wedding day" - offer the visual representation of an episode that is an ellipsis in the text: Marianne and Colonel Brandon's wedding does not feature in the novel. Marriage is the symbol of the happy ending (see Lodge and Bordwell), and Lee makes it the centrepiece of his epilogue. 

audibly. The resolution, Edward's declaration and proposal to Elinor not actually represented but observed by the other Dashwood women shown in medium shots displaying their strong emotion is followed by a cut to a procession of unknown children sauntering and shouting around a wedding cake. With these images of joyful village children arriving to accompany the couple coming out of church, the wedding is fully celebrated as a social event that gathers the community together. Social harmony, joy and happiness are the order of the day with smiling faces, music and blue skies.

The epilogue goes over all the characters amidst the crowd of villagers as they come out of church (Marianne and Brandon, Margaret and her mother, Elinor and Edward, Mrs Jennings and Sir John, Mr and Mrs Palmer, Fanny and John Dashwood) but with little emphasis on any of them. The camera lingers slightly on Elinor and Edward. A few shots on Marianne turning a loving face to a beaming Brandon and later peacefully smiling when sitting in the carriage ascertain the happiness of all - and deny any doubt one may have had reading the novel as to Marianne's feelings. Apart from these, no close shot to single out a character or emphasize emotions as this epilogue typically bids farewell to the characters that recede in the distance via, for instance, high angle shots and an extreme long shot as the closing image. We can recognize here a form of leave-taking of the characters called "anonymization" (Christen qtd in Hock 72) : the individual characters disappear into a larger crowd. Ang Lee multiplies the signs of closure with the actual leave-taking of Marianne and Colonel Brandon getting in a carriage (see Hock 72).

Just as the image invites "de-focalization" (Hock), so does the sound as there is no dialogue but only mixed voices with nothing distinct, cries of children and the intradiegetic music of the fiddle player preceding Colonel Brandon and Marianne out of the church. This is then drowned by extradiegetic music, louder as Colonel Brandon and Marianne come out of the church to indicate to the viewer that this is the climax. Focusing on the wedding conveys a sense of poetic justice at work. For North, "the wedding scene functions principally as a visually sumptuous romantic climax, smoothing over troubling aspects of the narrative" (49). It is true that the theme of injustice that pervades the last chapter of Austen's novel does not appear in the last scene of the film where Lucy Ferrars's successful fate is not mentioned at all. The epilogue may display the typical closure pattern but the wedding scene is not however a scene of reconciliation. John and Fanny Dashwood's presence at the wedding is indeed not to be seen as an indication of family unity and reconciliation. Fanny does not sincerely partake in the ambient joy : she is her usual disagreeable and displeased self as indicated in a shot that shows her complaining about rice being thrown over her head. Significantly, she is shown indicating to her husband where the money is to be picked up, when Colonel Brandon throws coins in the air. This also acts as a reminder of her behaviour at the beginning of the film when she steers John towards keeping all the money given by his father to themselves. Another shot with the same effect of framing or bracketing with content-related symmetry (see Hock 73) shows Brandon throwing the coins in the air for the village children to pick up. Indeed, as pointed out by Bordwell, "Not only does the epilogue reinforce the tendency toward a happy ending; it also repeats connotative motifs that have run throughout the film" (Narration 159). Thompson and Lee have made the male heroes lovable and loved by the heroines, so that the emphasis can lay on love marriages, instead of suggesting 
marriage is an economic transaction which in the novel appears in the story of Eliza being married to the elder Brandon ${ }^{11}$, in Willoughby's attraction for Miss Grey, and in John Dashwood's approach to his sisters' marriageability. Yet, if the theme of economic reality or tyranny does not prevail in the film epilogue as it does in the novel, these final shots of the coins in the air certainly remind the viewer of the centrality of money to the characters' lives and relationships.

\section{Conclusion}

In Austen's Sense and Sensibility, averting poetic justice is not merely an attempt at realism as suggested by Lloyd W. Brown but also a way of criticising society. If, among Austen's novels, this one is "the most attuned to progressive social criticism" (Johnson 49 ), it is undoubtedly due to its qualified use of poetic justice. Sense and Sensibility finally reads as a "comedy of manners," which "tends to reward its cleverly unscrupulous characters rather than punish their immorality" (Baldick). Ang Lee's adaptation offers a different picture as, like many other Hollywood adaptations, it tends to promote poetic justice via the representation of Marianne and Brandon's wedding. While, as we have seen, the romantic resolution is doubtful in Austen's novel, Lee makes it the centrepiece of his film's epilogue, yet without eschewing the impact of money. The heritage film genre to which Lee's Sense and Sensibility belongs is often taxed with nostalgia, presenting the past as idyllic (see, for instance, Higson). Lee's emphasis on economic issues visible in their bracketing shots that foreground the weight of the economic issues faced by the women but on which they have no hold and no say protects his film from such accusation and gives its ending a bittersweet taste.

Examining other Austen screen adaptations, Nixon notes that in the novels, " $(\mathrm{t})$ he marital reward is characterized by restraint ; while the film adaptations of Emma and Persuasion end with an emotional, physical kiss" (25). Thompson's script also included a kiss between Elinor and Edward (Gay 105) but it was significantly discarded by Ang Lee who, even if he does insist on a romantic resolution, does it with a restraint that is quite Austenian.

\section{BIBLIOGRAPHY}

Austen, Jane. Sense and Sensibility. 1811. Oxford : Oxford University Press, 2004.

---. Pride and Prejudice. 1813. Harmonsdworth : Penguin, 1985.

---. Northanger Abbey. 1818. Oxford : Oxford University Press, 1990.

Baldick, Chris. Concise Dictionary of Literary Terms. 1990. 2nd edition. Oxford : OUP, 2001.

Bordwell, David. “Happily Ever After, Part 2". Velvet Light Trap 19 (1982) : 2-7.

---. Narration in the Fiction Film. London : Routledge, 1985.

Brown, Lloyd W. “The comic conclusion in Jane Austen's novels” PMLA 84.6 (1969) : 1582-1587. 
Brownstein, Rachel. "Northanger Abbey, Sense and Sensibility, Pride and Prejudice". In The Cambridge Companion to Jane Austen. Ed. Edward Copeland and Juliet McMaster. Cambridge : Cambridge University Press, 1997. 32-57.

Butler, Marilyn. Jane Austen and the War of Ideas. Oxford : Clarendon Press, 1975. 2nd ed. 1990.

Copeland, Edward. "Money". In The Cambridge Companion to Jane Austen. Ed. Edward Copeland and Juliet McMaster. 2nd ed. Cambridge : Cambridge University Press, 2011. 127-143.

Forster, E. M. Aspects of the Novel. 1927. London : Penguin, 2005.

Gay, Penny. "Sense and Sensibility in a postfeminist world : sisterhood is still powerful". In Jane Austen on Screen. Ed. Gina MacDonald and Andrew MacDonald. Cambridge : Cambridge University Press, 2003. 90-110.

Higson, Andrew. 'Re-Presenting the National Past : Nostalgia and Pastiche in the Heritage Film'. In British Cinema and Thatcherism. Ed. Lester Friedman. London : UCL Press, 1993. 109-129.

Hock, Tobias. "Film endings". In Last Things : Essays on Ends and Endings. Ed. Gavin Hopps et al. Aachen British and American studies 19. Frankfurt : Peter Lang, 2014. 65-79.

Hudelet, Ariane. "Deciphering Appearances in Jane Austen's novels and films". In The Cinematic Jane Austen. Ed. David Monaghan et al. Jefferson (North Carolina) : McFarland, 2009. 76-93.

Johnson, Claudia L. . Jane Austen, Women, Politics and the Novel. Chicago : University of Chicago Press, 1988.

Jones, Vivien. "Feminisms". In A Companion to Jane Austen. Ed. Claudia Johnson and Clara Tuite. London : Wiley-Blackwell, 2011. 282-291.

Kaplan, Deborah. "Mass Marketing Jane Austen : Men, Women and Courtship in Two Film Adaptations". In Jane Austen in Hollywood. Ed. Linda Troost and Sayre Greenfield. Lexington : The University Press of Kentucky, 1998. 177-187.

Lee, Ang, dir. Sense and Sensibility. Perf. Emma Thompson, Alan Rickman, Kate Winslet, Hugh Grant. Columbia, 1995. Film.

Lodge, David.“Ambiguously ever After : Problematical Endings in English Fiction”. Working with Structuralism. London : Routledge and Kegan, Paul, 1981. 143-155.

Murphy, Olivia. "Texts and Pretexts : Sense and Sensibility and Pride and Prejudice". Jane Austen the Reader : The Artist as Critic. London : Palgrave Macmillan, 2013. 53-90.

Nixon, Cheryl L.. "Balancing the Courtship Hero : Masculine Emotional Display in Film Adaptations of Austen's novels". In Jane Austen in Hollywood. Ed. Linda Troost and Sayre Greenfield. The University Press of Kentucky, 1998. 22-43

North, Julian. "Conservative Austen, Radical Austen : Sense and Sensibility from Text to Screen". In Adaptations : From Text to Screen, Screen to Text. Ed. Cartmell, Deborah and Imelda Whelehan. London : Routledge, 1999. 38-50.

Poovey, Margaret. The Proper Lady and the Woman Writer, Ideology as Style in the Works of Mary Wollstonecraft, Mary Shelley, and Jane Austen. Chicago : The University of Chicago Press, 1984.

Rymer, Thomas. The Tragedies of the Last Age Consider'd. 1678. The Critical Works of Thomas Rymer. Ed. Curt A. Zimansky. New Haven : Yale University Press, 1956.

Samuelian, Kristin Flieger. "'Piracy is our only option' : Postfeminist intervention in Sense and Sensibility". In Jane Austen in Hollywood. Ed. Linda Troost and Sayre Greenfield. The University Press of Kentucky, 1998. 148-158. 
Sutherland, Kathryn. "Jane Austen on Screen". In The Cambridge Companion to Jane Austen. Ed. Edward Copeland and Juliet McMaster. 2nd ed. Cambridge : Cambridge University Press, 2011. 215-231.

Thompson, James. "Sororadelphia, or "even the conjugal tie is beneath the fraternal" ‘. Persuasions on Line 30 :1 (Winter 2009) http://jasna.org/persuasions/on-line/vol30no1/ thompson.html

Tremblet, Aurélie. "Jane Austen et les liens du mariage dans Sense and Sensibility : de véritables dénouements ?" In Jane Austen, Sense and Sensibility. Ed. Jean-Charles Perquin. Paris : Ellipses, 2015. 51-68.

\section{NOTES}

1. As E.M. Forster pointed out, "If it was not for death and marriage I do not know how the average novelist would conclude" (94).

2. For Poovey too, Sense and Sensibility begins like a novel of social realism (188) and "gestures towards realism" (193).

3. See Hudelet for the idea that films do not translate the equivocity of the novel endings (Hudelet 77)

4. Colonel Brandon is a positive character who lives comfortably but we are given to understand that he is not amongst the wealthiest characters: Mrs Jennings first declares him "rich" (28) but she later confides to Elinor that "[t]he estate at Delaford was never reckoned more than two thousand a year, and his brother left every thing sadly involved" (53). We understand that 2000 pounds does not compare with her "ample jointure" (28). For Copeland, "[a]t $£ 2,000$ a year [...], domestic economy must still hold a tight rein" (132). It is indeed much less that what John Dashwood who, with Norland, has " $[t]$ he prospect of four thousand a year, in addition to his present income, besides the remaining half of his mother's fortune [...]" (5).

5. Compare "Elinor was left to improve her acquaintance with Robert, who, by the gay unconcern, the happy self-complacency of his manner while enjoying so unfair a division of his mother's love and liberality, to the prejudice of his banished brother, earned only by his own dissipated course of life, and that brother's integrity, was confirming her most unfavourable opinion of his head and heart" (225) and John Dashwood's gradual acquiescence to his wife's belief that he need not do anything for his sisters in chapter 2 .

6. "setting aside the jealousies and ill-will continually subsisting between Fanny and Lucy, in which their husbands took part, as well as the frequent domestic disagreements between Robert and Lucy themselves, nothing could exceed the harmony in which they all lived together" (287).

7. "his punishment was soon afterward complete in the voluntary forgiveness of Mrs Smith, who, by stating his marriage with a woman of character, as the source of her clemency, gave him reason for believing that had he behaved with honour toward Marianne, he might at once have been happy and rich" (288).

8. For Poovey, "At the end of the novel, Austen ushers Marianne into Brandon's world of diminished wishes in such a way as to make Marianne herself negate everything she has previously wanted to have and to be" (189). 
9. See also Tremblet who sees it as endangering the relationship with their respective husbands (62).

10. On the "improvement" of male characters, see also Kaplan.

11. "Her fortune was large, and our family estate much encumbered. And this, I fear, is all that can be said for the conduct of one, who was at one her uncle and guardian"

(153).

\section{ABSTRACTS}

Jane Austen rewards her heroines with a marriage at the end of her novels but the question arises as to whether these marriages are a sign of poetic justice whose existence is not a given in Sense and Sensibility. Contrasting views point to an ambiguity inherent in the 1811 text, an ambiguity which will be explored in the course of this paper. The novel was adapted to the screen by Ang Lee in 1995 in a big-budget Columbia pictures film and we shall also examine what happens to this ambiguity regarding poetic justice in the film considering adaptations often lose in subtlety and prefer to promote a marked happy ending. This paper thus proposes to reexamine the presence or absence of poetic justice in the endings to the novel and to its film adaptation as an indication of the critical commentary each work offers on the society it depicts.

On sait que Jane Austen récompense ses héroïnes par des mariages à la fin de ses romans mais l'on peut se demander si ces unions sont le signe d'une justice poétique. Des points de vue critiques opposés ont en effet mis à jour une ambiguïté sur ce point dans Sense and Sensibility, ambiguïté que notre étude explorera. Ce roman paru en 1811 fut adapté à l'écran par Ang Lee en 1995 dans une production à grand budget et nous examinerons également ce qu'il advient de l'ambiguïté concernant la justice poétique dans ce film, dans la mesure où les adaptations cinématographiques d'Austen privilégient la représentation d'un "happy end" accentué. Cet article propose donc de se pencher à nouveau sur la question de la présence ou absence de justice poétique à la fin du roman et à la fin du film comme signe du commentaire critique que chaque œuvre offre sur la société dépeinte.

\section{INDEX}

Subjects: Film adaptations

Mots-clés: Sense and Sensiblity, Jane Austen, Ang Lee, fin de film, fin de roman, epilogue, marriage, héros, justice poétique

Keywords: Sense and Sensibility, Jane Austen, Ang Lee, film endings, novel endings, epilogues, marriage, heroes, poetic justice 
AUTHORS

ARMELLE PAREY

Maître de conférences

Université de Caen Normandie

armelle.parey@unicaen.fr 